\title{
Karl Kraus
}

\section{Gunther Martens \\ (Ghent University)}

\author{
[Preliminary draft, liable to complete change. Please refer to \\ the published version only.]
}

Karl Kraus: verbal collage technique and ready-made

From an institutional point of view, it might seem ludicrous to associate Karl Kraus, a famous Austrian polemicist and publicist, with an internationally grounded label such as modernism. The Austrian publicist is renowned for his fierce opposition to Expressionism (Franz Werfel, most prominently) and for his allegiance to both canonical and non-canonized poetae minores. Within the Austrian context, a notable critic has recently blamed Kraus for having successfully prevented the establishment of a literary avantgarde prior to WW2 altogether. This mainly alludes to the fact that experimental literature in Austria gained notoriety only through the work of the Wiener Gruppe and its concrete poetry. In the following, I will in order to arrive at the conclusion that Kraus anticipates many of the avant-garde actionist practices and may be seen as a precursor to, if not the embodiment of pre-WW2 in Austrian literature.

As a literary critic, he blamed Expressionism for its philosophical idealism and blind humanism, the poetic "Oh Mensch"-pathos which was indeed in many cases easily infected by patriotism and nationalism at the beginning of World-War I. ${ }^{1}$ Moreover, he opposed the desintegration of syntax as a giving way to psychoanalytical depth structures. Zohn points out that in addition Futurism, Cubism and Surrealism were being championed by the German literary critic Herwarth Walden and his review Der Sturm, suggesting that the growing rivalry was a further reason for Kraus to reject avant-garde authors. At the same time, Kraus published and helped individual writers such as Georg Trakl, Else Lasker-Schüler (at that time, Walden's wife) and Frank Wedekind (as detailed in Zohn 1996). Similarly relentless was Kraus' resistance to the ornamentalism of Klimt and the Vienna Secession. Especially the later Kraus seemed to give up entirely on modern art, cherishing a restricted sphere of 
"classical" artistic production, epitomized by Goethe, Nestroy, Offenbach and Shakespeare.

Nevertheless, Kraus' activities performed a quest for controversy and parody that qualifies him for a somewhat different perspective on the invention of politics through literary practices. Comparable to the majority of the avant-garde movements, the early Kraus criticizes bourgeois art, society and mentality: "This bourgeois face, emblem of a confident, progressive, secular and commercial civilization, which is Kraus's central target in the final years before 1914" (Timms 1986: 142). It is clear that his critique is motivated somewhat differentlythan that of avant-garde movements, although it remains difficult to assess his position in terms of institutional politics and parties. Kraus is often attributed "conservative leanings in the final years before 1914" (Timms 1986: 142). His early satires are held to testify to a "partiality": they fiercely attack anything related to liberal media (to a large extend owned by Jews), whereas his critiques tended to be far less concerned with corrupt aristocrats.

Kraus specialized in aphorisms which depicted women as creatures dominated by sexuality, erotic desire and irrationality. The description of women as destructive femmes fatales may seem very problematic from a feminist point of view, but in its context it was primarily meant to flout and contradict the sacrosanct mother role attributed to women by bourgeois conventions. Nike Wagner points out Kraus' role as a bourgeois scare, a "Bürgerschreck" (Wagner 1980: 164) and maintains that these provocative statements reveal more about the (fears besetting) the social construction of masculinity than about the nature of women. The provocative impact of Wedekind's (early expressionist) plays resided in a similar foregrounding of youthful and female sexuality. Kraus helped Wedekind to get the controversial play Pandora's Box (1904) staged in Vienna.

Surely this does not (and is not meant to) turn Kraus into an expressionist or an avant-garde author. Focussing on the direct expression of themes ${ }^{2}$, networks, parties and ethnic identities in his writings would contribute to a rather dubious though widespread tendency, namely to credit ambiguous and shifting speech acts with a downright institutional-political and over-all heteronomic value. In this register, Kraus has been taken to task for his presumed "silence" about the rise of National Socialism, his support for the Austro-fascist Dollfuß as the lesser evil, and for the fact that he did not risk to publish a lengthy Sprachkritik of fascist ideology, epitomized in the 
catchy slogan " $\mathrm{Zu}$ Hitler fällt mir nichts ein [My mind is a blank on Hitler]".

Beyond the schemata and categorisations that invite institutional attention, on the level of actual writing practices, Kraus has practiced forms and techniques that have become crucial for the understanding of the avant-garde. He invented a written brand of collage and montage techniques, producing essays and "compiling" dramatic characters that consisted almost entirely out of ready-made quotations. $^{3}$

It could be countered, of course, that the act of making these quotations perform differently relies heavily on a more classical institutional authority that Kraus had gained. It is indeed the case that the act of quoting and recontextualizing itself leaves a stylistic mark, especially when framed by operations of satire and ironical distancing. Especially when reading the satirical drama Literatur oder Man wird doch da sehn ("Literature or we'll see", 1921), which climaxed Kraus' argument with Franz Werfel and with expressionism in general, one gets the impression that literary texts are made to serve the distribution of sympathies, rumours, influence spheres - and even a competition for the favour of a female object of desire, Countess Sidonie Nádherny! (Leubner 1996: 236) Such redundantly argumentative texts, however, primarily add to the representation of authorship and authority in discourse. Parody and pastiche as a genre are prone to serve institutional purposes: since the quoted utterances are clearly identifiable as belonging to another author, they strengthen the identity of the one appropriating utterances (in terms of property) rather than a fluid dynamic of language to be actively embodied. There is a double form of intentionalism and subjectification of meaning underlying the act of parody: somebody is actively making utterances mean something different than what they were "meant to mean". When reading Kraus' parodies of expressionism, one begins to understand what Roland Barthes meant by "the wall of voice".

With regard to texts that frame ideologies as discursive procedures, however, I think it is wrong to create by all means the impression that their quotational tendency leads to plurivocity ${ }^{4}$, that - in this context it approximates the heterogeneous and collective origin that Walter Benjamin advanced as hallmark of the avant-garde revolution in art. Kraus diverts and mediates the verbatim quotation through very authorly and authorial procedures that turned out to be influential for modernist and postmodernist authors like Robert Musil and Elfriede Jelinek. To give a more specific example: The Fackel-text Die Orgie 
(1911) sets out to show that the newspaper Neue Freie Presse was blatantly supporting the election campaign of the liberal party. Kraus actively intervened in the "campaign" by sending a fake "letter to the editor' that consisted out of the phrases and partialness amalgamated out of the editorials themselves. The editors resorted to legal means in order to contain Kraus' guerrilla tactics by indicting him with "disturbing the serious business of politicians and editors". Kraus continued to comment these institutional measures as linguistic exchanges. Interpreters have gone at great lengths to balance the linguistic precision of the procedure with the doxic impurity it accumulates. ${ }^{5}$ In ideological terms, Kraus can indeed be seen to mount the argumentative force of a very intuitive type of "current awareness" (widespread stereotypes about women, Hungarians and Jewish journalists) in ways that at first sight may lead (and have lead) to consider the actual target of criticism, the lack of differentiation between propaganda and the press, as the lesser evil.

Kraus' style is at times so hermetic and long-winded that it seems to contradict its apparent aim to mobilize and rally support for its local causes. Especially attempts to label his writings with an aristocratic and reactionary political tendency are treated with a vertigo of overdeterminations that negates any attempt to translate its "operation" into party doctrine or other forms of institutional backup. Its contrived play with citation and comment simultaneously exposes and exploits intuitive argumentative procedures. It both exposes and exploits that e.g. heaping too much information (especially by way of appositions) on the thema-part of a sentence is an index of argumentation short-circuited into persuasion (Kraus 1989: 280). This creates a form of negativity which is not a simple variation of the blissful negation of politics through form (as developed by Adorno). On the contrary, Kraus keeps referring to the political and social problems of his time with an explicitness that is almost disturbingly detailed and that does not involve any gesture of silence. One is forced to conclude that Kraus aimed to address debates and controversies deeply entrenched in existing ideological forefronts for the sake of revealing by way of metadiscourse the ""pouvoir de denomination" (Bourdieu) in its production stages. In terms of performativity, Kraus' monomaniacal quest is not just about the media giving in to politics or commerce, it shows that the struggle for meta-language, as evidenced in incriminatory portraits and external attributions of intention, is at the core of the mediation of the political. ${ }^{6}$ 


\section{BIBLIOGRAPHY}

Baßler, Moritz. 1994. Die Entdeckung der Textur. Unverständlichkeit in der Kurzprosa der emphatischen Moderne 1910-1916. Niemeyer: Tübingen.

Berman, Jessica. 2001. Modernist Fiction, Cosmopolitanism, and the Politics of Community. Cambridge: Cambridge University Press.

DiBattista, Maria and Lucy McDiarmid, (eds). 1996. High and Low Moderns: Literature and Culture, 1889-1939. New York: Oxford University Press.

Einstein, Carl. 1998. Bebuquin oder die Dilettanten des Wunders. Stuttgart: Reclam.

Fish, Stanley. 1976. "How to Do Things with Austin and Searle: Speech Act Theory and Literary Criticism". In: Modern Language Notes 91: 983-1025.

Genette, Gérard. 1991. Fiction et diction. Paris: Seuil.

Hillis Miller, Joseph. 2001. Speech acts in literature. Stanford: Stanford University Press.

Kraus, Karl. 1989. Untergang der Welt durch schwarze Magie. Frankfurt: Suhrkamp.

Lensing, Leo A. 1990. "In the Wiener Werkstätten of the mind". The Not-So-Fine Arts in Karl Kraus' Die Fackel", in: Strelka, Joseph P. (ed.): Karl Kraus. Diener der Sprache. Meister des Ethos. Tübingen: Francke.

Leubner, Martin. 1996. Karl Kraus' "Literatur oder Man wird doch da sehn". Genetische Ausgabe und Kommentar. Göttingen: Wallstein Verlag.

Liska, Vivian. 2004. "Vorhut und Nachträglichkeit. Das Unzeitgemäße des deutschen Expressionismus", in: Klinger/Müller-Funk (2004): 133-144.

Martens, Gunther. 2001. "Literature and ethics in a polycontextural society: Niklas Luhmanns Systems-theoretical perspective". In: Bart Keunen and Bart Eeckhout (eds). Literature and Society. The Function of Literary Sociology in Comparative Literature. Brussels: P.I.E-Peter Lang: 157-178.

Martens, Gunther. 2006. Beobachtungen der Moderne in Hermann Brochs Die Schlafwandler und Robert Musils Der Mann ohne Eigenschaften. Rhetorische und narratologische Aspekte von Interdiskursivität. München: Wilhelm Fink Verlag. (= Musil-Studien; Bd. 35)

Mouffe, Chantal. 1996. "Deconstruction, Pragmatism and the Politics of Democracy", in: Mouffe, Chantal (ed.), Deconstruction and Pragmatism. London and New York: Routledge: 1-12.

Silverstein, Michael and Greg Urban. 1996. "The natural history of discourse". In: M. Silverstein und G. Urban (eds.): Natural Histories of Discourse. Chicago: University of Chicago Press: 1-17.

Stark, Michael. 1998. "Manifeste des 'neuen Menschen'. Die Avantgarde und das Utopische", in: Hubert van den Berg/Ralf Grüttemeier (eds) Manifeste. Intentionalität. Amsterdam \& Atlanta: Rodopi: 91-118.

Timms, Edward. 1986. Karl Kraus, Apolyptic Satirist: Culture and catastrophe in Habsburg Vienna. New Haven: Yale University Press.

Vogel, Juliane:

Wagner, Birgit. 1997. "Auslöschen, vernichten, gründen, schaffen: zu den performativen Funktionen der Manifeste", in: "Die ganze Welt ist eine Manifestation". Die europäische Avantgarde und ihre Manifeste. Darmstadt: Wissenschaftliche Buchgesellschaft: 39-57.

Wagner, Nike. 1982. Geist und Geschlecht, Karl Kraus und die Erotik der Wiener Moderne. Frankfurt a. M.: Suhrkamp. 
Zohn, Harry. 1994. "Karl Kraus und der Expressionismus", in: Amann, Klaus/ Wallas, Armin A. (eds) Expressionismus in Osterreich: Die Literatur und die Künste. Wien: Bohlau: 515-25.

\footnotetext{
${ }^{1}$ On the ideological and totalitarian tendencies ascribed to Expressionism, see e.g. Stark (1998). Liska (2004) states correctly that expressionism has not really been served by either philosophical 'updates' or ritualized obituaries (Liska 2004: 134). She links the avant-gardist core of expressionism with - I would say: more performative - concepts of trauma, fear and dream.

${ }^{2}$ Similar vague claims (based on the theme of sexuality in Young Törleß, 1906) have temporarily made Robert Musil to function as an "ancestor" of expressionism. Musil mockingly commented this "lineage" as the evolutionary proximity of "an orang outang to mankind". (Musil 1978, vol. 9: 1483)

3 Leo Lensing has even argued that Kraus' early newspaper photo manipulations as "assisted ready-mades" are "photomontage[s] similar to the corrected masterworks of the Dadaists" (Lensing 1990: 221): they are both "satirical response to the ideological distortions of the mass media" (Lensing 1990: 2001). It seems a bit exaggerated, however, to call Kraus an ancestor of "Otto Grosz, Heartfield, Klaus Staeck, Hans Haacke and John Berger"(ibid.). ${ }_{5}^{4}$ For a more extensive development of this argument, see Martens 2005.

5 "The validity of Kraus's critique of systems of communication is not impaired by that undercurrent of antisemitism" (Timms 1986: 146).

${ }^{6}$ From a discourse analytical perspective, Silverstein and Urban define "[p]olitics" as "the struggle to entextualize authoritatively, and hence, in one relevant move, to fix certain metadiscursive perspectives on texts and discourse practices" (1996: 11). The struggle for meta-denomination and the "acceptance of a metadiscourse by a community" is a process "at the very center of a community's organizing social categories and their relationship, including political hierarchies" (1996: 12).
} 